\title{
Acid resistance of dental enamel treated with remineralizing agents, Er:YAG laser and combined treatments
}

\section{Odporność szkliwa na kwasy po zastosowaniu środków remineralizujących, lasera Er:YAG i ich połączenia}

\author{
Alma Y. Ceballos-Jiménez ${ }^{1, B-D, F}$, Laura E. Rodríguez-Vilchis ${ }^{1, A-F}$, Rosalía Contreras-Bulnes ${ }^{1, A-F}$, Jesús Á. Arenas Alatorre ${ }^{2, A, C, F}$, \\ Ulises Velazquez-Enriquez ${ }^{1, C, E, F}$, Maria M. García-Fabila ${ }^{3, B, F}$ \\ ${ }^{1}$ Advanced Studies and Research Center, Faculty of Dentistry, Autonomous University of the State of Mexico, Toluca, Mexico \\ ${ }^{2}$ Department of Condensed Matter, Institute of Physics, National Autonomous University of Mexico, Mexico City, Mexico \\ ${ }^{3}$ Instrumental Analysis Laboratory, Institute of Chemistry, Autonomous University of the State of Mexico, Toluca, Mexico \\ A - research concept and design; $B$ - collection and/or assembly of data; $C$ - data analysis and interpretation; \\ $D$ - writing the article; $E$ - critical revision of the article; $F$ - final approval of the article
}

Address for correspondence

Laura E. Rodríguez-Vilchis

E-mail: rovilaster@gmail.com

Funding sources

None declared

Conflict of interest

None declared

Acknowledgements

This research was supported by the Autonomous University

of the State of Mexico and the National Autonomous University of Mexico.

Received on June 5, 2018

Reviewed on June 28, 2018

Accepted on August 3, 2018

DOI

10.17219/dmp/93960

Copyright

○ 2018 by Wroclaw Medical University

and Polish Dental Society

This is an article distributed under the terms of the

Creative Commons Attribution Non-Commercial License

(http://creativecommons.org/licenses/by-nc-nd/4.0/)

\begin{abstract}
Background. It has been reported that lasers can increase resistance to enamel acids, and when it is associated with fluoride, both are reported to work in synergy, achieving a reduction of the solubility of enamel. Currently, other remineralizing agents have been shown to effectively inhibit enamel demineralization.

Objectives. The aim of the study was to evaluate acid resistance in the occlusal surface of permanent teeth, treated with remineralizing agents, erbium-doped yttrium aluminum garnet (Er:YAG) laser and combined treatments.
\end{abstract}

Material and methods. Eighty samples of enamel were randomly assigned to 8 groups $(n=10)$ : a control group, and groups treated with sodium fluoride (NaF), casein phosphopeptide-amorphous calcium phosphate with NaF (CPP-ACPF), hydroxyapatite-NaF-xylitol (HA-NaF-X), Er:YAG laser (L), L+NaF, L+CPP-ACPF, and $L+H A-N a F-X$. The samples were placed in an acid solution and the released calcium (Ca) was quantified by atomic absorption spectrometry.

Results. In the groups treated with $\mathrm{NaF}$ and $\mathrm{L}+\mathrm{NaF}$, a lower loss of Ca was observed $-15.27 \pm 5.17 \mathrm{mg} / \mathrm{L}$ and $15.20 \pm 3.85 \mathrm{mg} / \mathrm{L}$, respectively - compared to the control group, which had the highest Ca loss: 21.93 $\pm 13.24 \mathrm{mg} / \mathrm{L}$.

Conclusions. Although the combination of Er:YAG laser plus NaF and the single application of NaF showed values suggesting superior resistance to demineralization of dental enamel compared to all the other groups in the study, no statistically significant differences were found to support this assertion.

Key words: erbium-doped yttrium aluminum garnet laser, occlusal surface, remineralizing agents, acid resistance

Słowa kluczowe: laser erbowo-jagowy, powierzchnia żująca, środki remineralizujące, odpornośćna kwasy 


\section{Introduction}

Dental enamel is the hardest of the mineralized tissues of the human body. ${ }^{1}$ Loss of this tissue can be caused by different processes in the oral cavity, namely attrition, erosion, abrasion, and tooth decay. ${ }^{2}$ In dental caries, this phenomenon occurs due to the presence of acids, which are a result of bacterial carbohydrate metabolism. First, a mineral loss occurs, and when it increases, it develops into a cavity. ${ }^{2,3}$ Once a cavity is formed, enamel cannot be repaired in a natural way and tooth restoration is necessary. ${ }^{3}$ Therefore, enamel resistance against acid attack must be increased before cavitation.

The effectiveness of fluoride for the prevention of dental caries has been clearly established in several studies. ${ }^{4}$ Furthermore, it enhances resistance to acid attack through the transformation of hydroxyapatite (HA) into fluorapatite. At the same time, it reduces the ability of bacteria to produce acid, having joint bactericide and remineralizing effects. ${ }^{5}$

Nowadays fluoride is added to several remineralizing agents available on the market in order to improve the ability of fluoride to restore the balance of minerals of the dental structure, such as casein phosphopeptide-amorphous calcium phosphate (CPP-ACP) and HA, among others. The anticariogenic properties of such remineralizing agents are explained by their mineral contribution to the dental structure - calcium $(\mathrm{Ca})$ and phosphorus $(\mathrm{P})$ ions, which inhibit demineralization and promote remineralization, resulting in the restoration of the dental surface.$^{6-11}$

Several studies have shown that laser irradiation using erbium-doped yttrium aluminum garnet (Er:YAG) laser at low energy settings increases fluoride absorption, and increases enamel resistance to acid attack more effectively than fluoride by itself. ${ }^{12-16}$ However, there are few studies that combine Er:YAG laser irradiation with remineralizing agents added to fluoride, such as CPP-ACP. ${ }^{17}$ Therefore, the purpose of this study was to evaluate acid resistance in the occlusal surface of permanent teeth, treated with remineralizing agents, Er:YAG laser and combined treatments.

\section{Material and methods}

\section{Ethical considerations}

This study was carried out after obtaining the approval of the Research Ethics Committee at the Advanced Studies and Research Center in the Faculty of Dentistry at the Autonomous University of the State of Mexico (Toluca, Mexico). All the subjects included in this research signed a consent form.

\section{Tooth selection and sample preparation}

Unerupted third molars, extracted for therapeutic reasons, were stored in $0.2 \%$ thymol solution at $4^{\circ} \mathrm{C}$ until required. The teeth were evaluated with the DIAGNOdent ${ }^{\circledR}$ pen (KaVo, Biberach, Germany) and 20 of them, with values between 0 and 13 (healthy teeth), were selected for the study. The molars were sectioned at the cementenamel junction with a BesQual diamond disc (Meta Dental Corp., Glendale, USA), mounted on a lowspeed motor (Brasseler USA, Savannah, USA) under deionized water irrigation. The crown was fixed to a glass slide with thermoplasticized epoxy resin (Allied High Tech Products Inc., Rancho Dominguez, USA). ${ }^{15,18-20}$ Buccolingual cuts were performed with a diamond wheel (South Bay Technology, Inc., San Clemente, USA) under constant irrigation to obtain 4 samples (2-millimeter wide). A reference line was marked $2 \mathrm{~mm}$ from the central occlusal fissure with a diamond disc (MDT Micro Diamond Technologies Ltd., Afula, Israel), mounted on a low-speed handpiece (MTI Dental, Coatesville, USA) to delimit the area to be treated. Subsequently, the specimens were cleaned in an ultrasonic bath (Quantrex ${ }^{\circledR}$ Q140; L\&R Ultrasonics, Kearny, USA) with deionized water for $5 \mathrm{~min}$ and dried at room temperature. ${ }^{21}$

A diagram of the experimental design is shown in Fig. 1.

\section{Surface treatments}

Eighty occlusal enamel samples were randomly assigned to 8 groups (10 per group). The samples were treated individually, as described below (Table 1).

Sodium fluoride: In this group, the samples were treated with a sodium fluoride $(\mathrm{NaF})$ gel (Flor-Opal ${ }^{\circledR}$; Ultradent Products, Inc., South Jordan, USA) at a concentration of $1.1 \%$ (5,457 ppm) for $4 \mathrm{~min}$.

CPP-ACPF: In this group, the specimens were treated with a cream containing CPP-ACP and NaF (900 ppm) (MI Paste Plus; GC Corporation, Tokyo, Japan) for $4 \mathrm{~min}$.

Hydroxyapatite: These samples were treated with a cream of HA, NaF (1,450 ppm) and xylitol (X) (Remin Pro ${ }^{\circledR}$, Voco $\mathrm{GmbH}$, Cuxhaven, Germany) for $4 \mathrm{~min}$.

After the application of the mineralizing agents, the samples were rinsed with deionized water for $30 \mathrm{~s}$ and dried at room temperature.

Table 1. Treatments by study groups

\begin{tabular}{|c|c|}
\hline Group & Treatment \\
\hline Control & no treatment \\
\hline $\mathrm{NaF}$ & sodium fluoride \\
\hline CPP-ACPF & $\begin{array}{c}\text { casein phosphopeptide-amorphous calcium } \\
\text { phosphate with } \mathrm{NaF}\end{array}$ \\
\hline $\mathrm{HA}-\mathrm{NaF}-\mathrm{X}$ & hydroxyapatite-NaF-xylitol \\
\hline$L$ & Er:YAG (100 mJ, $\left.12.7 \mathrm{~J} / \mathrm{cm}^{2}, 10 \mathrm{~Hz}\right)$ \\
\hline $\mathrm{L}+\mathrm{NaF}$ & Er:YAG (100 mJ, $\left.12.7 \mathrm{~J} / \mathrm{cm}^{2}, 10 \mathrm{~Hz}\right)+\mathrm{NaF}$ \\
\hline$L+C P P-A C P F$ & Er:YAG $\left(100 \mathrm{~mJ}, 12.7 \mathrm{~J} / \mathrm{cm}^{2}, 10 \mathrm{~Hz}\right)+C P P-A C P F$ \\
\hline$L+H A-N a F-X$ & Er:YAG $\left(100 \mathrm{~mJ}, 12.7 \mathrm{~J} / \mathrm{cm}^{2}, 10 \mathrm{~Hz}\right)+\mathrm{HA}-\mathrm{NaF}-\mathrm{X}$ \\
\hline
\end{tabular}

Er:YAG - erbium-doped yttrium aluminum garnet laser. 


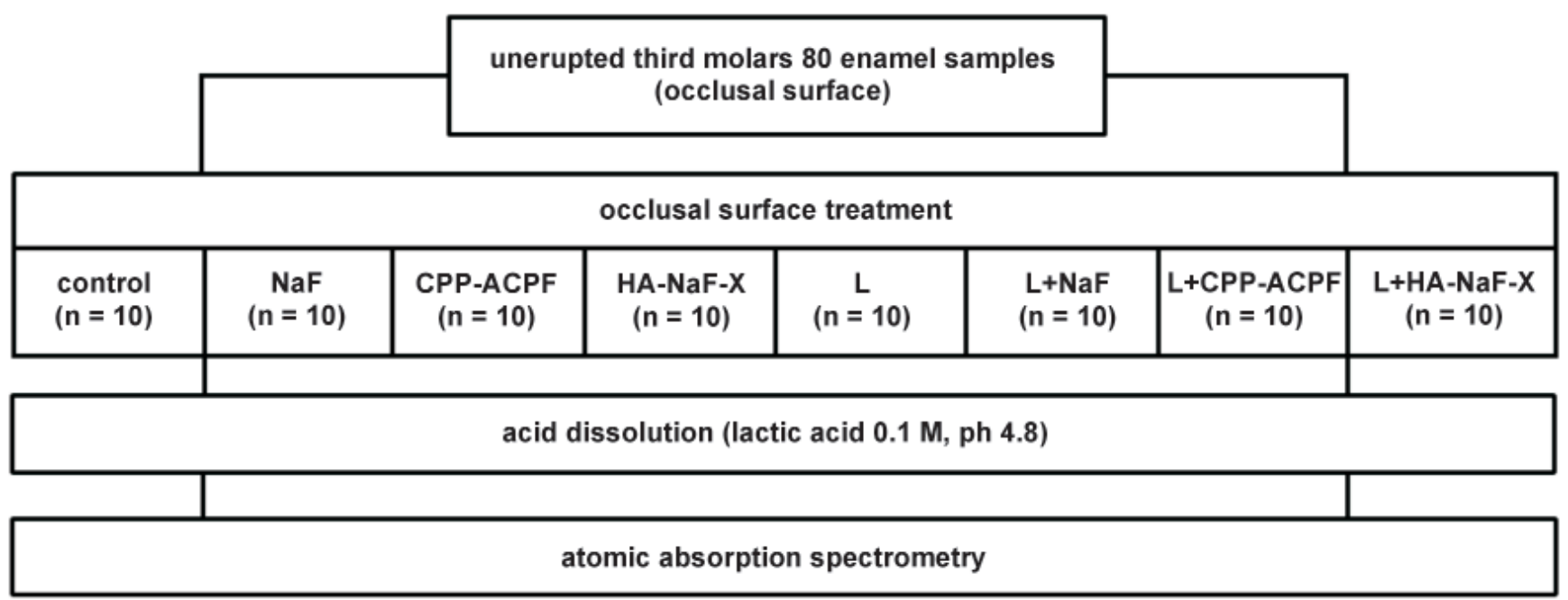

Fig. 1. Diagram of the experimental design

Er:YAG laser irradiation: The irradiation of the samples was carried out using an Er:YAG laser system (OpusDuo AquaLite $^{\circledR}$ EC, Er:YAG $+\mathrm{CO}_{2}$; Lumenis Ltd., Yokneam, Israel). The laser parameters used were as follows: wavelength $-2.94 \mu \mathrm{m}$; pulse energy - $100 \mathrm{~mJ}\left(12.7 \mathrm{~J} / \mathrm{cm}^{2}\right)$; frequency - $10 \mathrm{~Hz}$; pulse duration - 250-400 $\mu \mathrm{s}$; and exit tip diameter $-1.0 \mathrm{~mm}$. The energy level was calibrated using the calipers of the equipment and the energy delivered was measured periodically with a power meter (LaserMate ${ }^{\circledR}$-P; Coherent, Inc., Santa Clara, USA). The dental surface was scanned manually with the sapphire tip of the laser perpendicular to it, at a working distance of $1 \mathrm{~mm}$ and with irrigation (distilled water $5 \mathrm{~mL} / \mathrm{min}$ ). ${ }^{15,18-21}$ Each sample was irradiated only once for $20 \mathrm{~s}$.

\section{Combined treatments}

In these groups, the samples were irradiated with Er:YAG laser. Then, the respective remineralizing agents were applied using the same techniques described above.

\section{Acid dissolution}

The samples were coated with an acid-resistant varnish, except the experimental area. Subsequently, all the samples were demineralized in $2 \mathrm{~mL}$ of $0.1 \mathrm{M}$ lactic acid, $\mathrm{pH} 4.8$, for $24 \mathrm{~h}$ in an incubator (Ikemoto Scientific Technology Co., Ltd., Tokyo, Japan) at $37^{\circ} \mathrm{C}$ and $100 \%$ humidity.

\section{Atomic absorption spectrometry}

After acid dissolution, the samples were rinsed with deionized water to remove $\mathrm{Ca}$ residues from the tooth surface. The amount of $\mathrm{Ca}$ released from the samples was obtained by atomic absorption spectrometry (atomic absorption spectrometer PU9100X; Philips NV, Amsterdam, the Netherlands).

\section{Statistical analysis}

All the data was analyzed using the SPSS statistical package, v.19 (IBM SPSS, Armonk, USA). The KolmogorovSmirnov test was used to assess the data distribution and the one-way analysis of variance (ANOVA) test was used to analyze the differences between the groups. A p-value $\leq 0.05$ was considered significant.

\section{Results}

A lower Ca loss (in $\mathrm{mg} / \mathrm{L}$ ) was observed in the groups treated with $\mathrm{NaF}$ and $\mathrm{L}+\mathrm{NaF}$. The control group had the highest loss of $\mathrm{Ca}$ (in $\mathrm{mg} / \mathrm{L}$ ), followed by the HA-NaF-X group. The statistical analysis revealed no statistically significant differences among the groups (Table 2).

Table 2. Mean values and standard deviations (SD) of calcium (Ca) released by study groups

\begin{tabular}{|l|l|l|}
\multicolumn{1}{|c|}{ Group } & Ca [mg/L] & $\begin{array}{c}\text { p-value } \\
\text { (ANOVA) }\end{array}$ \\
\hline Control & $21.93(13.24)$ & \\
NaF & $15.27(5.17)$ & \\
CPP-ACPF & $20.67(6.30)$ & 0.346 \\
HA-NaF-X & $21.13(7.26)$ & \\
L & $18.80(5.45)$ & \\
L+NaF & $15.20(3.85)$ & \\
L+CPP-ACPF & $17.00(5.67)$ & \\
L+HA-NaF-X & $17.07(3.66)$ & \\
\hline
\end{tabular}

ANOVA - analysis of variance. 


\section{Discussion}

Pit-and-fissure caries remains the most common form of this disease, ${ }^{22}$ and caries prevention on the occlusal surface continues to be a challenge in dentistry. There are a few reports regarding laser-combined protocols for caries prevention on the occlusal surface that have studied the effect of Nd:YAG+APF (acidulated phosphate fluoride) (1.23\%), ${ }^{23} \mathrm{CO}_{2}+\mathrm{NaF}(5 \%),{ }^{24}$ and recently Er:YAG+fluoride with CPP-ACP. ${ }^{17}$ For the present work, the occlusal enamel surfaces from third molars were selected to evaluate enamel acid resistance after the application of several remineralizing agents ( $\mathrm{NaF}-1.1 \%$, CPP-ACPF - 900 ppm and HA-NaF-X - 1,450 ppm), Er:YAG laser and combined treatments.

Some studies have tested Er:YAG laser irradiation at lower energy densities and have shown significant inhibition of enamel demineralization. ${ }^{14,25}$ This reduction has been attributed to the surface temperature achieved during enamel laser irradiation, and loss of water and carbonate. ${ }^{26}$ In the current study, the selected parameters (low energy density - $12.7 \mathrm{~J} / \mathrm{cm}^{2}$; pulse energy - $100 \mathrm{~mJ}$; frequency - $10 \mathrm{~Hz}$; pulse duration - 250-400 $\mu \mathrm{s}$, and water irrigation $-5.0 \mathrm{~mL} / \mathrm{min}$ ) were based on previous studies $^{16,21}$ and the results of a pilot study.

Three remineralizing agents were chosen, with $\mathrm{NaF}$ representing fluoride as the keystone of caries prevention, which has been widely studied. ${ }^{5} \mathrm{HA}-\mathrm{NaF}-\mathrm{X}$ and CPP-ACPF were employed as alternative methods to fluoride.

Remin Pro (HA-NaF-X) was selected, because HA is an important biomaterial, a source of $\mathrm{Ca}$ and $\mathrm{P}$. Remin Pro additionally promotes the remineralization of demineralized enamel areas, ${ }^{10}$ since it contains xylitol, which assists in the remineralization of tooth enamel, ${ }^{27}$ and also contains $\mathrm{NaF}(1,450 \mathrm{ppm})$.

MI Paste Plus ${ }^{\mathrm{TM}}$ (CPP-ACPF) was included in this study, because at an acidic $\mathrm{pH}$ CPP-ACP separates amorphous calcium phosphate (ACP) from casein phosphopeptide (CPP), thereby increasing salivary $\mathrm{Ca}$ and $\mathrm{P}$ levels, and promoting carious lesion remineralization. ${ }^{8}$ Furthermore, it also contains $\mathrm{NaF}$ (900 ppm), whose fluoride ion can be exchanged with the hydroxyl group in the apatite crystal to form fluorapatite, which is a more stable and less soluble crystal. ${ }^{28}$

The groups treated with these remineralizing pastes showed no statistically significant differences in comparison with the control group. The reason could be that a single application of these remineralizing agents to the dental structure may not be enough to increase acid resistance. However, a 30\% reduction in the loss of Ca content observed in the $\mathrm{NaF}$ and $\mathrm{L}+\mathrm{NaF}$ groups in comparison with the control group could have clinical significance. Moreover, a previous study reported an increase in the $\mathrm{Ca} / \mathrm{P}$ ratio under similar conditions for treatments with $\mathrm{L}+\mathrm{NaF}, \mathrm{L}+\mathrm{HA}-\mathrm{NaF}-\mathrm{X}, \mathrm{L}$, and $\mathrm{NaF}$, in decreasing order. ${ }^{21}$
However, Comar et al. ${ }^{11}$ reported that fluoride paste $(0.2 \% \mathrm{NaF})$ is still the best option for reducing dental demineralization in vitro when compared to HA, CPP-ACP and CPP-ACPF. The use of lasers in combination with CPP-ACPF and HA-NaF-X showed a superior performance, which was a promising result. The above-mentioned authors found that the reduction in released $\mathrm{Ca}$, caused by the application of each of these remineralizing agents alone amounted to $5.75 \%$ and $3.65 \%$ respectively, while there was a reduction of $22 \%$ for the combined treatments in comparison with the control.

In the present study, Er:YAG laser irradiation as a single treatment had a lower preventive effect than in the $\mathrm{NaF}$ group and all the combined groups. Thus, under the conditions studied, it should be applied in combination with a remineralizing agent. Contrary to the results of this study, Díaz-Monroy et al. reported a higher resistance to acidic dissolution when the samples were irradiated at a density of $12.7 \mathrm{~J} / \mathrm{cm}^{2}$, without using water to irrigate during irradiation. ${ }^{20}$ Additionally, Cecchini et al. found that Er:YAG laser irradiation at lower energies can decrease enamel solubility without severe alterations of the tooth structure, even under the cooling effect of water flow. ${ }^{29}$ Furthermore, Bevilácqua et al. concluded that Er:YAG laser irradiation combined with topical application of fluoride (APF gel) showed a beneficial effect on enamel acid resistance; they also reported that a higher energy density $\left(31.84 \mathrm{~J} / \mathrm{cm}^{2}\right) \mathrm{re}-$ sulted in a greater resistance to mineral loss. ${ }^{13}$

The findings of Liu et al. showed that a combination of $\mathrm{NaF}(2 \% / 9,047 \mathrm{ppm})$ and Er:YAG laser $\left(5.1 \mathrm{~J} / \mathrm{cm}^{2}\right)$ provided a higher preventive effect for human dental enamel, followed by laser irradiation (41.2\%) and fluoride alone (28.9\%), but the treatment conditions and evaluation techniques differed from those used in the current study. ${ }^{14}$

The results indicate that additional studies are required to deepen our knowledge of the insufficiently explored area of remineralizing agents in combination with Er:YAG laser. Evaluation of combined treatments in consecutive applications, as well as higher energy densities for Er:YAG laser irradiation, are suggested.

\section{Conclusions}

A single application of $\mathrm{NaF}$ alone and the application of $\mathrm{NaF}+\mathrm{Er}$ :YAG laser showed similar lower values of $\mathrm{Ca}$ released, compared to the control group, the groups treated with $\mathrm{CPP}-\mathrm{ACPF}$ and $\mathrm{HA}-\mathrm{NaF}-\mathrm{X}$ with (i.e., control+laser, CPP-ACPF+laser and HA-NaF-X+laser) and without laser. These results could imply that a single $\mathrm{NaF}$ application and $\mathrm{NaF}+$ laser offer a superior resistance to the demineralization of dental enamel in comparison with the other treatments studied; however, the statistical analyses showed no statistically significant differences among the groups, so there is not enough statistical evidence to claim a superior acid resistance. 


\section{References}

1. Berkovitz BKB, Moxham BJ, Linden RWA, Sloan AJ. Master Dentistry Volume Three: Oral Biology. $3^{\text {rd }}$ ed. Beijing, China: Elsevier; 2011:142.

2. West NX, Joinerb A. Enamel mineral loss. J Den. 2014;42s1:s2-s11.

3. Featherstone JDB. Dental caries: A dynamic disease process. Aust Dent J. 2008;53(3):286-291.

4. Splieth $\mathrm{CH}$, Christiansen J, Foster Page LA. Caries epidemiology and community dentistry: Chances for future improvements in caries risk groups. Outcomes of the ORCA Saturday Afternoon Symposium, Greifswald, 2014. Part 1. Caries Res.2016;50(1):9-16.

5. Jones S, Burt BA, Petersen PE, Lennon MA. The effective use of fluorides in public health. Bull World Health Organ. 2005;83(9):670-676.

6. lijima Y, Cai F, Shen P, Walker G, Reynolds C, Reynolds EC. Acid resistance of enamel subsurface lesions remineralized by sugar-free chewing gum containing casein phosphopeptide-amorphous calcium phosphate. Caries Res. 2004;38(6):551-556.

7. Kumar VLN, Itthagarum A, King NM. The effect of casein phosphopeptide-amorphous calcium phosphate on remineralization of artificial caries like lesions: An in vitro study. Aust Dental J. 2008:53(1):34-40.

8. Reynolds EC. Casein phosphopeptide-amorphous calcium phos phate: The scientific evidence. Adv Dent Res. 2009;21(1):25-29.

9. Tschoppe P, Zandim DL, Martus P, Kielbassa AM. Enamel and dentin remineralization by nano-hydroxyapatite toothpaste. J Dent. 2011;39(6):430-437.

10. Gjorgievska ES, Nicholson JW, Slipper IJ, Stevanovic MM. Remineralization of demineralized enamel by toothpaste: A scanning electron microscopy, energy dispersive X-ray analysis, and three-dimensional stereo-micrographic study. Microsc Microanal. 2013;19(3):587-595.

11. Comar LP, Souza BM, Gracindo LF, Buzalaf MA, Magalhães AC. Impact of experimental nano-HAP pastes on bovine enamel and dentin submitted to a pH cycling model. Braz Dent J. 2013;24(3):273-278.

12. Ana PA, Bachmann $L$, Zezell DM. Lasers effects on enamel for caries prevention. Laser Physics. 2006;16(5):865-875.

13. Bevilácqua FM, Zezell DM, Magnani R, da Ana PA, Eduardo Cde P. Fluoride uptake and acid resistance of enamel irradiated with Er:YAG laser. Lasers Med Sci. 2008;23(2):141-147.

14. Liu Y, Hsu CY, Teo CM, Teoh SH. Potential mechanism for the laser-fluoride effect on enamel demineralization. J Dent Res. 2013;92(1):71-75.

15. Zamudio-Ortega CM, Contreras-Bulnes R, Scougall-Vilchis RJ, et al. Morphological and chemical changes of deciduous enamel produced by Er:YAG laser, fluoride and combined treatment. Photomed Laser Surg. 2014;32(5):252-259.

16. Curylofo-Zotti FA, Solano Tanta G, Zugliani AL, Milori Corona SA. The combined use of sodium fluoride and Er:YAG laser to control the progression of enamel caries. Eur J Pharm Med Res. 2016;3(9):1-5.

17. Yassaei S, Shahraki N, Aghili H, Davari A. Combined effects of Er:YAG laser and casein phosphopeptide-amorphous calcium phosphate on the inhibition of enamel demineralization: An in vitro study. Dent Res J (Isfahan). 2014;11(2):193-198.

18. Rodríguez-Vilchis LE, Contreras-Bulnes R, Sánchez-Flores I, Samano EC. Acid resistance and structural changes of human dental enamel treated with Er:YAG. Photomed Laser Surg. 2010;28(2):207-211.

19. Rodríguez-Vilchis LE, Contreras-Bulnes R, Olea-Mejìa OF, SánchezFlores I, Centeno-Pedraza C. Morphological and structural changes on human dental enamel after Er:YAG laser irradiation: AFM SEM and EDS evaluation. Photomed Laser Surg. 2011;29(7):493-500.

20. Díaz-Monroy JM, Contreras-Bulnes R, Olea-Mejía OF, et al. Chemical changes associated with increased acid resistance of Er:YAG laser irradiated enamel. Sci World J. 2014;2014:501357:1-6.

21. Ceballos-Jiménez AY, Rodríguez-Vilchis LE, Contreras-Bulnes R, et al. Chemical changes of enamel produced by sodium fluoride, hydroxyapatite, Er:YAG laser, and combined treatments. J Spectroscopy. 2018;2018:1-7.

22. Carvalho JC. Caries process on occlusal surfaces: Evolving evidence and understanding. Caries Res. 2014;48(4):339-346.

23. Zezell DM, Boari HG, Ana PA, Eduardo Cde P, Powell GL. Nd:YAG laser in caries prevention: A clinical trial. Lasers Surg Med. 2009;41(1):31-35.
24. Rechmann P, Charland DA, Rechmann BM, Le CQ, Featherstone JD. In-vivo occlusal caries prevention by pulsed $\mathrm{CO}_{2}$-laser and fluoride varnish treatment: A clinical pilot study. Lasers Surg Med. 2013;45(5):302-310.

25. Liu Y, Hsu CYS, Teo CMJ, Teoh SH. Subablative Er:YAG laser effect on enamel demineralization. Caries Res. 2013;47(1):63-68.

26. Nelson DGA, Wefel JS, Jongebloed WL, Featherstone JD. Morphology, histology and crystallography of human dental enamel treated with pulsed low-energy infrared laser radiation. Caries Res. 1987;21(5):411-426.

27. Mäkinen KK. Sugar alcohols, caries incidence, and remineralization of caries lesions: A literature review. Int J Dent. 2010;2010:1-23.

28. Venkatesan K, Ranjan M. Remineralizing agents in dentistry: A review. J Dent Med Sci. 2014;13:57-60.

29. Cecchini RC, Zezell DM, de Oliveira E, de Freitas PM, Eduardo Cde P. Effect of Er:YAG laser on enamel acid resistance: Morphological and atomic spectrometry analysis. Laser Sur Med. 2005;37(5):366-372. 
